\title{
ASPEK GRAMATIKAL SYAIKH NAWAWI AL-BANTANI (PERSPEKTIF LINGUISTIK ARAB)
}

\author{
Kamran Asat Irsyady \\ e-mail: kamran@radenintan.ac.id \\ UIN Raden Intan Lampung
}

\begin{abstract}
Nahwu merupakan ilmu 'alat' untuk memahami bahasa keislaman, dan salah satu matn nahwu yang paling banyak mendapat apresiasi luas adalah al-Muqaddimah al-Ajurrümiyyah karya Ibnu Ajurrüm ( Abū Abdullāh Muhammad aș-Sinhäjī 672-723 H) yang dikembangkan oleh para ulama selanjutnya dalam bentuk syarh, nażm, hasyiyyah, dan taqrïät, salah satunya Syaikh Muhammad Nawawi al-Bantani (12301314 H/1815-1897 M) dengan judul: Fath Gäfir al-Khatiyyah 'ala al-Kawākib al-Jaliyyah fi Nazm alAjurrümiyyah. Kitab nahwu Nawawi ini bercorak ta'Timí (pedagogik) dan didesain untuk kepentingan pembelajaran dengan gaya narasi yang sederhana, sistematis, dan minim perdebatan masalah khilafiyyah, disertai contoh-contoh kreatif. Tulisan ini menemukan bahwa Syaikh Nawawi memberikan tambahan dengan menghadirkan contoh-contoh yang sedikit banyak berkaitan dengan isu-isu pendidikan dan keislaman, seperti ilmu dan belajar dan proses belajar-mengajar antara guru-murid, hingga isu-isu teologis seperti muslim dan kafir, di samping isu-isu lingkungan, perjalanan, dan interaksi sosial dalam kehidupan sehari-hari.
\end{abstract}

Keywords: gramatikal Arab, ulama Jawi, al-Ajurrumiyyah

\section{PENDAHULUAN}

Disiplin nahwu (tata bahasa Arab) merupakan salah satu bidang kajian yang mendapat perhatian luas kalangan ulama mengingat pentingnya bahasa Arab sebagai instrumen dasar atau 'ilmu alat' untuk memahami berbagai ilmu pengetahuan, tentu saja yang berbahasa Arab, atau untuk mengekspresikannya.

Mengutip penelitian Muhidin ${ }^{1}$, dari 900 kitab kuning yang beredar di lingkungan pesantren, hanya sekitar $20 \%$

1 Akhmad Muhidin, Pemikiran Syaikh Nawawi al-Bantani (1813-1897): Studi atas Pengaruhnya dalam Pembelajaran Pesantren, Skripsi Jurusan Sejarah dan Peradaban Islam Fakultas Adab UIN Sunan Kalijaga 2005, hlm. 43. (dua puluh persen) saja yang bersubstansikan fikih, sementara sisanya menyangkut disiplin ilmu-ilmu keagamaan yang lain dengan komposisi sebagai berikut: bahasa Arab (nahwu, sharaf, dan balaghah) sebanyak $17 \%$, tasawuf $18 \%$, tafsir (?), hadis nabi $7 \%$, akhlak $6 \%$, sejarah Islam (sirah, maulid, dan manaqib) $6 \%$, dan pedoman doa (wirid dan mujarabat) $5 \%$ Jika dilakukan peringkasan, maka hanya ada dua disiplin ilmu utama saja yang tampak berkembang, yakni fikih dan tasawuf, plus disiplin ilmu bahasa Arab. Sejajarnya disiplin ilmu bahasa Arab dengan disiplin ilmu fikih dan tasawuf mengandung arti 
bahwa diskursus intelektual yang berkembang di kalangan pesantren mensyaratkan penguasaan bahasa Arab sebagai ilmu bantu untuk memahami teksteks fikih, tasawuf, dan teks-teks keagamaan yang lain.

Salah satu matn nahwu yang paling banyak diminati dan mendapat apresiasi luas di kalangan pesantren dan kalangan akademisi Arab adalah alMuqaddimah al-Ajurrumiyyah karya Ibnu Ājurrūm (Abū Abdullāh Muhammad ibnu Muḥammad ibnu Dāwud aṣ-Ṣinhāji 672$723 \mathrm{H}$ ) yang dikembangkan dalam bentuk syarh, nażm, hasyiyyah, dan taqrïrät. ${ }^{2}$ Menurut catatan bibliografis Hāji Khalifah dalam Kasyf az-Zunūn, kitab

2 Matn adalah teks awal yang berisi prinsip-prinsip dasar suatu disiplin yang dihimpun dalam sebuah risalah kecil yang bersih dari penjelasan elaboratif, syawāhid, dan contoh kecuali dalam batas-batas darurat. Sementara syarh adalah teks kedua yang menjelaskan hal-hal yang masih samar dalam matan, memperinci halhal yang global. Sedangkan hāsyiyah adalah penjelasan elaboratif atas matn atau syarh dengan menguraikan hal-hal yang obscure, mempermudah hal-hal yang sulit, mengisi hal-hal yang terlewatkan, menggaris-bawawhi hal-hal yang keliru dan membenarkannya, memberikan tambahan yang bermanfaat, dan menambah syawāhid maupun contoh. Adapun taqrirāt adalah catatan kaki yang di sisi naskah atas poin tertentu dalam syarah atau hasyiyah. Lihat Ahmad ibnu Muhammad ad-Dabīb, "Tahqiq at-Turās alLughawi wa Nasyruhu fi Mamlakah al'Arabiyyah as-Su'ūdiyyah", dalam Majalah Majma' al-Lughah al-'Arabiyyah, Cairo-Mesir, Edisi 90 Tahun 1999, hlm. 81. turunan yang lahir dari matan ini mencapai ratusan. ${ }^{3}$

Apresiasi kreatif terhadap matn alAjurrümiyyah maupun kitab turunannya juga diberikan oleh ulama-ulama nusantara, terutama mereka yang pernah mengenyam pendidikan di Haramain yang kemudian dikenal dengan sebutan "Așhāb al-Jâwiyyin̄" [Komunitas Intelektual Jawa $]^{4}$. Syaikh Muhammad ibnu 'Umar an-Nawawi $\bar{i} \quad$ al-Bantani $\quad$ (w. 1316 H) misalnya menulis dua syarah atas matan

3 Lihat Hāji Khalifah (Mustafāa ibnu Abdullāh), Kasyf az-Zunūn 'an Usāmā al-Kutub wa al-Funūn, (Beirut: Dār Ihya' at-Turās al'Arabi, t.t.), 2/1796-1798.

Data lebih detail dikemukakan oleh Abū Bakr ibnu Abd al-Wahhāb sebagai berikut: Syarh berjumlah 109 buah, dengan ḥāsyiyah turunan berjumlah 27 buah. Sementara itu, karya nazmnya berjumlah 17 buah, dan dari nazm ini lahir syarah atas nazham yang berjumlah 9 buah. Sedangkan karya turunan dalam bentuk pengi'rāb-an teks matan berjumlah 7 buah. Lihat Abu Bakr ibnu Abd al-Wahhāb, At-Ta'riff bi alAjurrūmiyyah: Mușannifuhā wa Mażhabuhu fi anNaḥw, Syurūhuhā, Manzūmātuhā, A'āribuhā, Ma Lahā wa Mama 'Alaihā, dalam Maktabah asySyamilah Versi 3.23, Arsyif Multaqa Ahl alHadits, 1/9391-9401.

${ }^{4}$ Istilah "Jawi", meski berasal dari kata Jawa, merujuk pada sebuah komunitas di Makkah dan Madinah (Haramain) yang berasal dari wilayah Nusantara, meliputi Indonesia, Malaysia, hingga Pattani (Thailand), atau Asia Tenggara pada umumnya. Santri-santri Jawi di Haramain inilah yang menurut penelitian Azyumadi Azri menjadi inti utama tradisi intelektual dan keilmuan Islam di wilayah Nusantara. Lihat Azyumardi Azra, Jaringan Ulama Timur Tengah dan Kepulauan Nusantara Abad XVII dan XVIII: Melacak Akar-akar Pembaruan Pemikiran Islam di Indonesia, cet. IV (Bandung: Mizan, 1998), hlm. 17. Lihat juga Ismawati, Continuity and Change: Tradisi Pemikiran Islam di Jawa Abad $X I X-X X$, (Jakarta: Badan Litbang \& Diklat Departemen Agama RI, 2006), hlm. 180. 
ini. Pertama syarah atas matan alAjurrumiyyah yang diberi judul: "Kasyf al-Murütiyyah 'an Sutūr alAjurrümiyyah" dan kedua syarah atas nazam Ajurrumiyyah Abdussalam anNibrawi yang menjadi bahasan penelitian. $^{5}$

Ulama nusantara anggota komunitas Ashhab al-Jawiyyin lainnya yang memberikan apreasiasi ilmiah terhadap al-Ājurrūmiyyah adalah Syaikh Muhammad Ma'ṣūm ibnu Sālim asSamarānì as-Safațūin (dari Kampung Sepaton Semarang yang merupakan salah satu guru dari Syaikh Muhammad Mahfūz at-Tarmasi (1285-1338 H). Ia menulis sebuah hāasyiyah atas Syarḥ alĀjurrūmiyyah Sayyid Aḥmad Zaini Dahlān (w. 1304) yang kemudian ia beri judul "Hāsyiyah Tasywīq al-Khillān 'ala Syarh al-Ajurrümiyyah li Ahmad Zaini Dahlāñ" ( Tasywìq al-Khillān anotasi atas komentar Ahmad Zaini Dahlan terhadap al-Ajurrūmiyyah). ${ }^{6}$

5 Kitab ini telah dicetak di Matba'ah Syaraf (Makkah) tahun 1298 H/1880 M. Lihat Yūsuf Alian Sarkis, Mu'jam al-Matbū'àt al'Arabiyyah wa al-Mu'arrabah, (Beirut: Mansyūrat Maktabah Ayatullāh al-Uẓmā al-Mar'asyi anNajafi, t.t.), 2/1882.

${ }^{6}$ Keterangan ini diisyaratkan sendiri oleh pengarang. Lihat Tasywiq al-Khillān, hlm. 197. Guru pengarang lainnya yang juga disinggung dalam kitab ini adalah Syaikh Isḥaq as-Samārāni. Lihat Muhammad Ma'sūm ibnu Sālim asSamārāni as-Safatūnī, Tasywīq al-Khillān Hāsyiyah 'ala Syarh al-Ajurrümiyyah li al'Allämah as-Sayyid Ahmad ibnu as-Sayyid Zainī
Berkebalikan dengan Syaikh Muḥammad Ma'șūm as-Samārāni yang karya nahwunya dikenal dan beredar di Indonesia, sementara ketokohannya kurang dikenal, karya nahwu Nawawi alBantani justeru tidak populer dan tenggelam oleh kepopuleran kitab-kitab di bidang lain yang dikaji secara luas di dunia pesantren. Padahal, Nawawi merupakan sosok ulama yang sangat piawai dalam menerangkan kata-kata dan kalimat-kalimat Arab yang artinya tidak jelas atau sulit dimengerti yang tertulis dalam syair terkenal yang bernafaskan keagamaan. Kepakaran Nawawi dalam bidang bahasa Arab pernah diuji di hadapan para syaikh Masjid al-Haram. Menurut cerita KH. Muslih 'Abdurrahman al-Maraqi (Mranggen, Demak), Syaikh Nawawi pernah dideportasi dari "Haram" akibat kecemburuan ulama setempat atas prestasi dan karir akademisnya, namun atas desakan para muridnya yang merasa kehilangan sang guru, Syaikh Aunurrafiq yang memegang otoritas penunjukan guru besar di Haram akhirnya memperbolehkan Nawawi untuk mengajar kembali di Haram dengan syarat ia mampu menjawab pertanyaan yang dirumuskan oleh para ulama Haramain,

Daḥlañ, (Semarang: PT. Thoha Putera, t.t.), hlm. 95. 
yaitu seputar makna gramatikal dan leksikal kata "lā siyyamā’. Pertanyaan ini dijawab oleh Syaikh Nawawi secara panjang lebar dalam surat sepanjang 15 halaman yang menguraikan secara tuntas asal-usul kata, kedudukan i'rab, sekaligus makna kata tersebut. ${ }^{7}$

Kepiawaiannya di bidang bahasa Arab ini bisa dijumpai hampir di seluruh karyanya, terutama dalam Tafsir Marāh Labï. Ia banyak menggunakan analisis kebahasaan dalam mengupas makna di balik ayat dengan menjelaskan kedudukan susunan kalimat dalam setiap ayat yang memiliki perbedaan qira'at, sehingga makna ayat menjadi jelas meski terdapat perbedaan qira'at. ${ }^{8}$ Penafsiran Nawawi, menurut Mamad. Burhanuddin, cenderung mengarah pada upaya pemahaman ayat al-Qur'an yang sedikit banyak dipengaruhi unsur subyektivitasnya sebagai seorang guru

\footnotetext{
7 Cerita ini dilansir oleh Aziz Masyhuri dalam 99 Kyai Kharismatik, hlm. 62-63. Karya yang mengurai tentang kata "la siyyama" ditulis oleh Syaikh Ahmad as-Suja'i dengan judul Manzumah La Siyyama yang kemudian diberi komentar oleh Syaikh Muhammad al-Amir dengan judul: Syarh al-'Allämah al-Amīr 'alā Nazm al-'Allamāh as-Sujā'i fi "Là Siyyamā”. Kitab ini ditahqiq oleh Dr. Ahmad ibnu Muhammad ibnu Ahmad al-Qursyi, seorang profesor madya (al-ustāí al-musā'id) di Kulliyyyah I'dād al-Mu'allimin (semacam IKIP) Madinah al-Munawwarah.

${ }^{8}$ Mamad S. Burhanuddin, Hermeneutika al-Qur'an ala Pesantren (Analisis terhadap Tafsir Marah Labid Karya KH. Nawawi Banten), (Yogyakarta: UII Press, 2006), hlm. 54-55.
}

yang moderat, intelektual yang tengah merespons perkembangan zaman, seorang mujaddid tanpa menafikan ulama salaf, seorang yang memiliki perhatian dan keprihatinan dengan tanah airnya. ${ }^{9}$

Lebih lanjut, sebagai seorang ulama yang berlatar-belakang Jawi dan berinteraksi dengan murid-murid yang kebanyakan berasal dari Jawi yang menurut pengamatan Snouck Hurgronje memiliki problem tersendiri dengan bahasa $\mathrm{Arab}^{1}$, Nawawi tentu saja mempertimbangkan konteks psikologi belajar mereka, apalagi kitab nahwu Fath Gāfir al-Khatiyyah yang menjadi kajian utama dalam penelitian ini ditulis atas permintaan salah seorang yang diduga kuat berasal dari murid kalangan Jawi. Apalagi dalam kitab tersebut, penulis juga menjumpai sisipan doa di akhir bahasan $B a b$ al-Hāl yang mengisyaratkan kepedulian nasib Nawawi akan kondisi faktual kala itu yang terjadi di tanah airnya. ${ }^{1}$

\footnotetext{
${ }^{9}$ Ibid., hlm. 213.

1 Lihat laporan C. Snouck Hurgro̊nje, Mekka
} in The Latter Part of The $19^{\text {th }}$ Century: Daily Life, Customs, and Learning Moslims of The East-IndianArchipelago, (Leiden: E.J. Brill, 1970), hlm. 269.

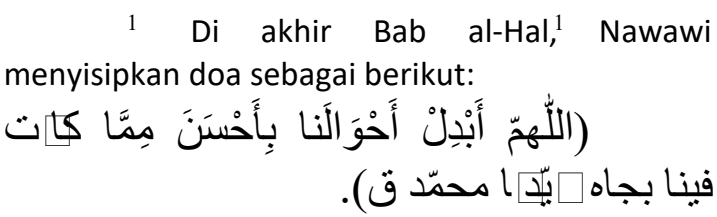

Lihat Naș Muhaqqaq, hlm. 195. 
Pertimbangan kontekstual dan situasional atau semangat zaman di mana Nawawi hidup, berinteraksi, dan berproses kreatif sedikit banyak bisa dirasakan ketika membaca contoh-contoh yang dikemukakan Nawawi dalam kitab nahwu ini. Sebagai seorang guru, di samping mengemukakan contoh-contoh yang sudah pakem dalam tradisi nahwu Arab yang aktor-aktotnya berkisar antara Zaid, Amru, Hind, Da'd dengan aktivitas yang berkutat pada datang-pergi (ja'ażahaba), lewat dan memukul (marrad̦araba), dan duduk-berdiri (jalasa-qāma), Nawawi memberikan tambahan dengan menghadirkan contoh-contoh yang sedikit banyak berkaitan dengan isu-isu pendidikan dan keislaman, seperti ilmu dan belajar dan proses belajar-mengajar antara guru-murid, hingga isu-isu teologis seperti muslim dan kafir. Sebagai sampel, lihat misalnya ketika Nawawi memberi contoh tentang musianna dan jama', serta hàal:

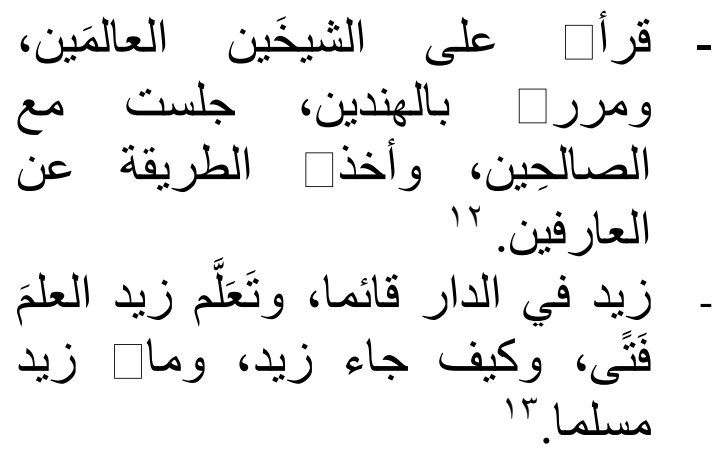

1 Ibid., hlm. 45.

1 Ibid., hlm. 189.
Pada sampel contoh di atas, Nawawi terlihat tetap mempertahankan lafal-lafal contoh yang sudah menjadi pakem dan mentradisi, namun Nawawi kemudian juga menambahinya dengan contoh berupa aktivitas-aktivitas lain dan aktor-aktor yang berbeda pula.

Tulisan ini ingin mengupas sisi gramatikal dalam biografi Syaikh Nawawi al-Bantani dan keunikan contoh-contoh nahwu dalam karya gramatikalnya. Penulis berusaha melakukan pembacaan contoh-contoh nahwu Nawawi yang bertema pendidikan mengingat keterbatasan waktu dan mempertimbangkan antara lain sinkronisasinya dengan corak nahwu Nawawi dalam naskah ini yang bercorak pedagogik ( $\operatorname{ta}$ ' $\lim \overline{1})$, dan latar belakang Nawawi sebagai pembelajar dan guru terkemuka bagi tokoh-tokoh pesantren Indonesia.

\section{LANDASAN TEORI}

\section{Biografi Syaikh Nawawi al-Bantani Nama dan Nisbat:}

Dalam karya-karyanya, Nawawi memperkenalkan dan mendefinisikan dirinya dengan sebutan definitif beragam yang menunjukkan nama diri, laqab, kunyah, dan nisbatnya, antara lain: 
Muhammad Nawawi, ${ }^{1} \quad$ Muhammad Nawawi al-Jāwi, ${ }^{1}$ Muhammad Nawawi ${ }^{5}$ asy-Syafi' ${ }^{1},{ }^{1}$ Muhammad Nawawi ${ }^{6}$ asySyafi'i al-Qādiri, ${ }^{1}$ Muhammad ibnu Umar al-Jāwi, ${ }^{1}$ Muhammad Nawawi ibnu Umar, ${ }^{1}$ Muhammad Nawawi Ibnu Umar al-Jāwi, ${ }^{2}$ Muhammad ibnu 'Umar ibnu 'Arabi ibnu 'Ali, ${ }^{2}$ Muhammad Nawawi ibnu 'Umar ibnu 'Arabi atTanarawi, ${ }^{2}$ Muhammad Nawawi ${ }^{2}$ ibnu 'Umar ibnu 'Arabi asy-Syafi' ${ }^{2}{ }^{2}$ Muhammad Nawawi ibnu 'Umar atTanari baladan al-Asy'ari i 'tiqadan asySyafi'i madzhaban, ${ }^{2}$ Abū 'Abd al-Mu'ți Muhammad Nawawi ibnu 'Umar al-Jāwì

\footnotetext{
1 Nawawi al-Bantani, At-Tafsirir al-Munir li Ma'ālim at-Tanzīl al-Musfir 'an Wujūh atTa'wìl -al-musammā tabaqan li ma'nahu-Marāh Labìd li Kasyf Ma'na Qur'ān Majìd, (Cairo: Maṭba'ah al-'Usmāniyyah, $1305 \mathrm{H})$, hlm. 1.

1 Nawawi, $A \dot{s}$-Simār al-Yāni'ah Syarh ar-Riyạ̄ al-Badíah (Cairo: Mustafa Babi alHalabi, 1317 H), hlm. 1; Marāqi al-'Ubūdiyyah, (Bandung: Al-Ma'arif, t.t.), hlm. 1; Salālim alFuḍala', (Tasikmalaya: Toko Baru, t.t.), hlm.1.

1 Nawawi, Nur az-Zalām, (Suŕabaya: AlHidayah, t.t.), hlm. 1.

1 Nawawi, Bahjah al-Wasā'il,'(Bandung: Al-Ma'arif, t.t.), hlm. 1.

1 Nawawi, Fath al-Majid, ('T.t.t.: Dar Ihya' al-Kutub al-'Arabiyyah, t.t.), hlm. 1.

1 Nawawi, Qāmi’at-Tugyān, Y'T.t.t.: Dar Ihya' al-Kutub al-'Arabiyyah, t.t.), hlm. 1.

2 Nawawi, Nașāih ${ }^{0}$ al-'Ibād, (Tasikmalaya: Toko Baru, t.t.).

2 Nawawi 'Uqūd al-Lujain, (Semarang: Thoha Putera, t.t.), hlm. 1

2 Naskah 61 B/8-9. 2

2 Nawawi, Qatr al-Gaïs, (T.t.t.: Dar Ihya' al-Kutub al-'Arabiyyah, t.t.), hlm. 1.

2 Nawawi, Nihāyah az-Zain fí Irsyād alMubtadi'in, (Beirut: Dar al-Fikr, t.t.), hlm. 1.
}

asy'-Syafi'i $\quad$ (madzhaban) al-Bantani (iqliman) at-Tanari (mansya'an wa däran) $/ .^{2}$

Merujuk deretan nama di atas, bisa disimpulkan bahwa nama Muhammad yang menempel di depan Nawawi adalah nama yang diberikan semenjak lahir. Sementara itu, sebutan "Abū 'Abd alMu'ți” adalah nama kunyah ${ }^{2}$, karena beliau menurut keterangan Rafi'uddin arRamli yang dikutip 3 oleh Ahmad memiliki seorang anak laki-laki tunggal bernama 'Abdul Mu'ti. ${ }^{2}$ Namun menurut sumbęr${ }^{4}$ sumber lain, tidak ada laporan yang menyebutkan Nawawi memiliki anak laki-laki. Data yang ada menyebutkan bahwa beliau memiliki dua orang isteri bernama Nasima yang berasal dari kampung halamannya dan Hamdana ${ }^{2}$. Dari isteri pertama, beliau dikarunia tiga orang anak perempuan bernama Ruqayyah, Nafisah, dan Maryam, sementara dari yang kedua beliau

2 Nawawi, Kāsyifah as-Saja, (Cairo: AlMațba'ah al-Maimaniyyah, 1298 H), hlm. 1

2 Nama kunyah adalah náma yang diawali dengan label ubuwwah, umumah, ukhuwwah, dan seterusnya.

2 Rafi'uddin Ramli dan dan Muhammad Fakhri, Sejarah Hidup dan Silsilah Kyai Muhammad Nawawi Tanara, (Cirumpak-Keronjo, Tangerang: Yayasan Nawawi Tanara, 1399), hlm. 3.

2 Chaidar, Sejarah Pujangga Islam Syech Nawawi Albantani Indonesia, (Jakarta: CV. Sarana Utama, 1978), hlm. 5. Sejauh ini tidak ada laporan yang berisi keterangan lengkap mengenai kedua isteri Syaikh Nawawi. 
dikaruniai seorang puteri bernama Zahrah. $^{2}$ 9

Ayah Nawawi bernama Haji 'Umar ibnu 'Arabi, seorang pegawai urusan agama pemerintah kolonial Belanda yang menjabat sebagai penghulu distrik ${ }^{3}$ (tingkat kecamatan), sementara ibunya bernama Jubaidah (Zubaidah). Dari silsilah ayahnya, Nawawi merupakan keturunan ke-11 dari Maulana Hasanuddin (pendiri Kerajaan Banten) yang bernasab hingga Rasulullah saw. ${ }^{3}$,

2 Asep Muhammad Iqbal, Yahudi dan Nasrani dalam al-Qur'an: Hubungan Antaragama menurut Syaikh Nawawi Banten, (Jakarta: Teraju, 2004), hlm. 50.

3 Penghulu berasal dari kata ${ }^{0}$ hulu yang berarti kepala. Mula-mula ia berarti orang yang memimpin, namun lama-kelamaan penghulu berubah dalālah menjadi seorang ahli dalam soal agama Islam yang diakui dan diangkat oleh yang berwajib (pemerintah). Jabatan penghulu memiliki tingkatan yang mengikuti tingkatan jabatan pemerintahan. Penghulu di ibu kota kabupaten disebut penghulu kepala, di bawahnya ada pegawai-pegawai yang lebih rendah lagi, yaitu penghulu distrik (tingkat kecamatan) dan penghulu onderdistrik (tingkat kelurahan) yang sering disebut naib ( $n a^{\prime} i b$ ) yang berarti pengganti penghulu kabupaten. Lihat lebih lanjut dalam G.F. Pijper, Beberapa Studi tentang Sejarah Islam di Indonesia 1900-1950, diterjemahkan oleh Prof. Dr. Tudjimah dan Dra. Yessy Augusdin, (Jakarta: UI Press, 1984), hlm. 67-100.

3 Silsilah lengkap Syaikh Nawawi dari garis ayah adalah sebagai berikut: Syaikh Muhammad Nawawi $\rightarrow$ Kyai Umar $\rightarrow$ Kyai Arabi $\rightarrow$ Kyai Ali $\rightarrow$ Kyai Jamad $\rightarrow \mathrm{Ki}$ Janta $\rightarrow \mathrm{Ki}$ Masbugil $\rightarrow \mathrm{Ki}$ Masqun $\rightarrow \mathrm{Ki}$ Masnun $\rightarrow$ Ki Maswi $\rightarrow$ Ki Tajul Arusy Tanara $\rightarrow$ Maulana Hasanuddin Banten $\rightarrow$ Maulana Syarif Hidayatullah Cirebon $\rightarrow$ Raja Amatuddin Abdullah $\rightarrow$ Ali Nuruddin $\rightarrow$ Maulana Jamaluddin Akbar Husain $\rightarrow$ Imam Sayyid Ahmad Syah Jalal $\rightarrow$ Abdullah 'Azmah Khan $\rightarrow$ Amir Abdullah Malik $\rightarrow$ Sayyid 'Alwi $\rightarrow$ Sayyid Muhammad Shahib Mirbath $\rightarrow$ Sayyid Ali Khali' Qasim $\rightarrow$ Sayyid sementara dari garis ibu ia adalah keturunan Muhammad Singaraja. ${ }^{3}$ Ia merupakan anak tertua dari 6 bersaudara. Adik laki-lakinya bernama Ahmad, Sa'id, Tamim, dan yang bungsu adalah Abdullah, sementara dua saudara perempuannya bernama Syakila dan Syahriya. $^{3}$

3

\section{Identitas Keilmuan:}

Nawawi merupakan sosok ulama multidisipliner darí abad XIV H. Dalam paparannya mengenai ulama-ulama Jawi (asal Nusantara) yang tinggal di Makkah, Hurgronje bahkan menobatkan Nawawi sebagai: "The most highly esteemed leaders of the intelectual movement" (tokoh pergerakan intelektual yang paling terkemuka). ${ }^{3}$ 4

Para penyusun biografi dan bibliografi karya-karya Nawawi menyebutnya dengan beragam gelar yang menunjukkan identitas keilmuannya, antara lain:

Alwi $\rightarrow$ Imam Ubaidillah $\rightarrow$ Imam Ahmad Muhajir Ilallah $\rightarrow$ Imam Isa an-Naqib $\rightarrow$ Imam Muhammad Naqib $\rightarrow$ Imam 'Ali ar-Ridhi $\rightarrow$ Imam Ja'far ashShadiq $\rightarrow$ Imam Muhammad al-Baqir $\rightarrow$ Imam Ali Zainal Abidin $\rightarrow$ Sayyidina Husain $\rightarrow$ Sayyidatuna Fathimah az-Zahra' $\rightarrow$ Muhammad Rasulullah saw. Lihat Ramli, Sejarah, hlm. 11-12.

$$
3 \text { Ibid. }
$$
Mekka, hlm. 268, 269. Chaidar, Sejarah, hlm. 8.

$$
3 \text { lbid. }
$$


- Doctor of divinity (pakar ilmu kalam dan ilmu-ilmu keagamaan $)^{3}$.

- Mufassir (ahli tafsir) dan mutas\}awwif (pengamal sufisme). ${ }^{3}$

Sufi, faqi $>h$ (ahli fikih), mutakallim (ahli ilmu kalam), dan pakar multidisipliner. ${ }^{3}$

\section{HASIL DAN PEMBAHASAN}

\section{Mengulas Contoh Gramatikal dalam Karya Nawawi}

Berdasarkan pembacaan induktif atas contoh-contoh yang dikemukakan oleh Nawawi dalam naskah ini, bisa dikemukakan bahwa secara garis besar Nawawi tetap mengikuti tradisi para ahli nahwu sebelumnya dalam penggunaan aktor dan aktivitas contohnya sebagai bentuk kesinambungan sejarah, di samping mengutip contoh yang dikemukakan para penulis kitab nahwu sebelumnya. Namun ia juga melakukan beberapa perubahan dengan menambahkan contoh-contoh baru yang lebih bervariatif dan 'bermakna'.

Contoh-contoh nahwu Nawawi ini bisa penulis klasifikasikan berdasarkan tematema yang diusungnya ke dalam lima kategori:

\footnotetext{
3 Snouck, Mekka, hlm. 268. 5

3 Az-Zirikli, al-A'lām, 6/318. ${ }^{6}$

3 Riḍa Kuḥālah, Mu'jam al’Mu'allifin,
} $11 / 87$.
1. Çontoh-contoh bertema pendidikan dan aktivisme pengajaran.

6 Contoh-contoh bertema ini memuat kata-kata kunci yang berkutat pada masalah ilmu dan hal-hal yang berkaitan dengannya, antara lain: 'ilm, jahl, 'ālim, māhir, jāhil, syaikh, 'ulamā, mudarris, ta'alamma, qara'a, darasa, akhaża 'an/min, talaba, tāla'a, kātib, alkitāb, dan sejenisnya. Contoh:

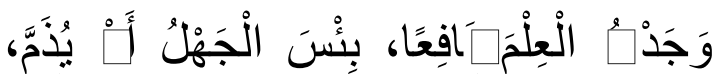

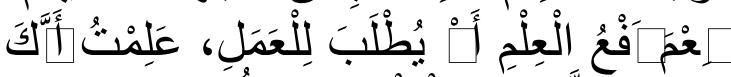

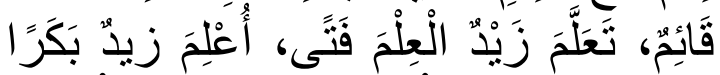

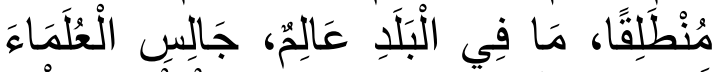

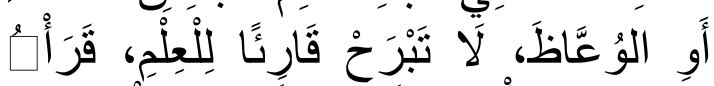

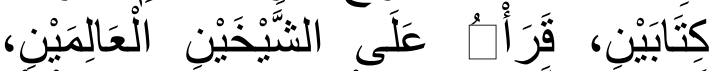

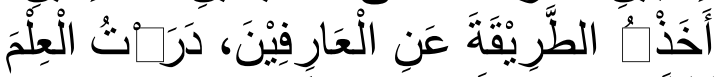

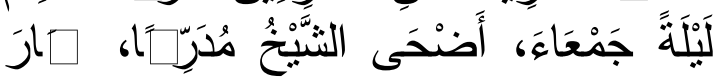
زَيْدِد مَاهِرًا.

2. Contoh-contoh bertema sufistik/pesan moral.

Contoh-contoh bertema sufistik/pesan moral dicirikan dengan pemakaian kata-kata kunci: kematian, devotisme, kezuhudan, dan kebaikan budi. Contoh:

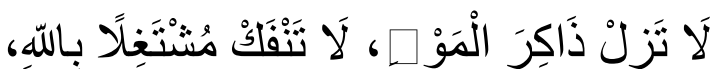

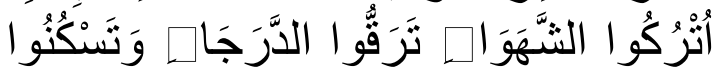

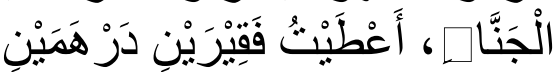


3. Contoh-contoh bertema fikih dan teologis.

Contoh-contoh bertema ini memuat kata-kata kunci yang terkait dengan ritual-ritual peribadatan, hubungan hamba dengan Tuhan, pengampunan, surga, muslim dan kafir, fasiq, surga, dan sejenisnya. Contoh:

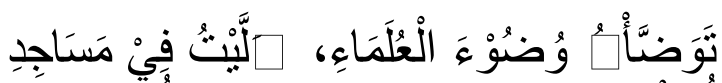

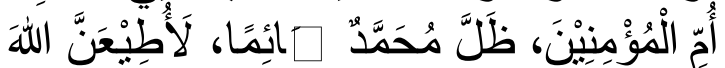

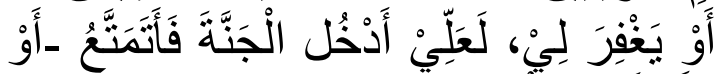

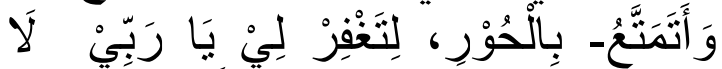

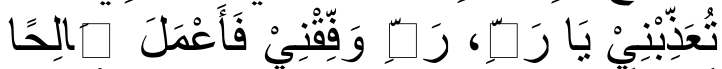

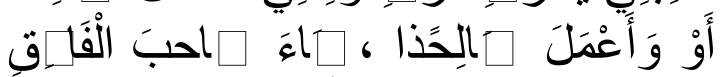

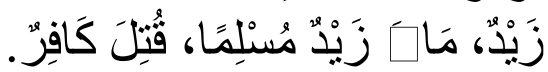

4. Contoh-contoh bertema lingkungan alam sekitar.

Contoh-contoh bertema ini memuat kata-kata kunci yang berkaitan dengan obyek-obyek alam, seperti gunung, bulan purnama, pohon, dan binatang. Contoh:

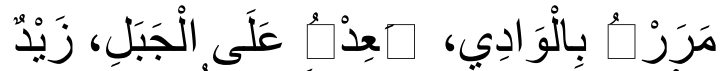

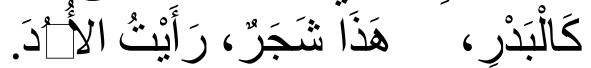

5. Contoh-contoh bertema safar

(perjalanan), antara lain:

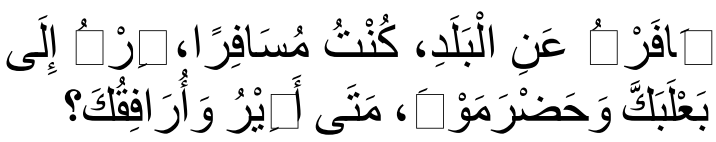

6. Contoh-contoh bertema kemanusiaan dan interaksi sosial.
Contoh-contoh bertema ini memuat kata-kata kunci yang berkaitan dengan masalah-masalah kemanusiaan dan tata hubungan kemasyarakatan, seperti hubungan sosial suami-isteri, keluarga, tamu, rumah, dan pertemanan. Contoh:

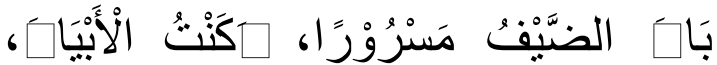

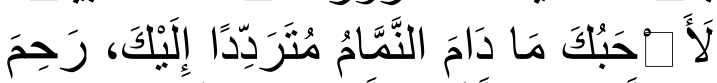

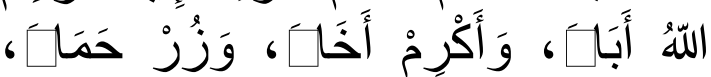

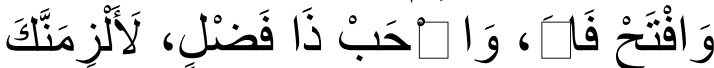

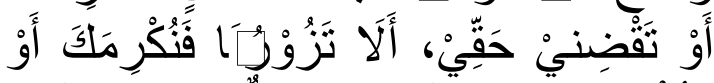

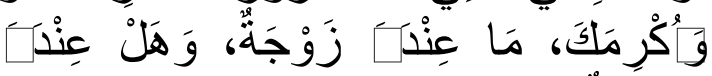

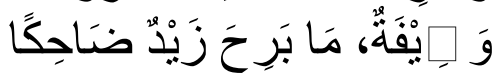

Dalam pembacaan ini, penulis menggunakan pendekatan hermeneutika Schleiermacher yang bertumpu pada asumsi bahwa teks merupakan sarana kebahasaan yang dapat mentransfer isi pikiran seorang pengarang kepada pembaca, dan tugas hermeneutik adalah memahami teks sebagaimana yang dipahami pengarang, bahkan melebihi pemahaman pengarang itu sendiri.

Untuk mendekati teks pengarang dan mencapai makna otentiknya, Schleiermacher mensyaratkan perlunya dua pendekatan sekaligus, yakni penafsiran gramatikal dan psikologis. 
Penggunaan pendekatan gramatikal

dibutuhkan karena pemahaman/penafsiran tidak bisa dilepaskan dari aspek-aspek kebahasaan, sementara pendekatan psikologis diperlukan karena kondisi kejiwaan pengarang sangat berpengaruh terhadap makna teks yang dihasilkannya. Di sini Schleiermacher mengharuskan seorang penafsir agar mensejajarkan dirinya dengan pengarang, dan menempati posisinya ketika melakukan rekonstruksi subjektif dan objektif terhadap pengalaman pengarang yang terkandung dalam teks.

Contoh-contoh Nawawi dalam hal ini bisa dikategorikan sebagai teks, karena ia dijadikan sebagai media oleh Nawawi dalam posisinya sebagai pengarang naskah nahwu- untuk menjelaskan kaidah-kaidah nahwu kepada pembaca. Contoh-contoh ini juga dimanfaatkan oleh Nawawi dalam posisinya sebagai guru untuk menyisipkan pesan-pesan tertentu kepada pembacanya yang notabene merupakan murid-muridnya, baik murid yang berguru langsung kepadanya maupun murid dalam arti intelektual dan spiritual.
Mengingat keberadaannya sebagai teks, maka contoh-contoh nahwu Nawawi pun secara teoretis maupun praktis bisa didekati dengan pendekatan hermeneutika Schleiermacher yang mensyaratkan pembacaan secara gramatikal (obyektif) dan psikologis (subyektif) guna menemukan makna otentik di balik teksteks contoh Nawawi tersebut.

Schleiermacher meyakini adanya makna final (makna otentik) bagi teks, dan untuk mencapainya maka keseluruhan kehidupan penyusun teks itu haruslah diketahui. Sementara penyingkapan niatnya pada saat khusus pembuatan karya tidaklah demikian penting dan berpengaruh. Dari sisi lain, setiap kali suatu karya memiliki tanda atau petunjuk atas keseluruhan keberhasilan penyusunnya maka untuk sampai kepada keseluruhan kehidupan penyusun karya tersebut diperlukan penyingkapan kekhususan jiwa dan kekhususan psikologi penyusun, perenungan terhadap teks itu sendiri, dan penyingkapan dari dimensi-dimensi karya itu. Oleh karena itu, Schleiermacher berkeyakinan bahwa untuk memahami perkataan penyusun 
mesti diketahui kepribadiannya dan keseluruhan kehidupannya, sementara untuk mengetahuinya dibutuhkan pemahaman gramatikal terhadap perkataannya.

Dari pembacaan gramatikal dan psikologis atas contoh-contoh Nawawi yang bertema pendidikan dan dikaitkan dengan contoh-contoh bertema lainnya, bisa ditarik benang merah bahwa makna otentik yang ingin dibangun Nawawi dalam pemberian contoh-contoh khas dalam karya nahwunya adalah urgensi ilmu dalam kehidupan. Ilmu merupakan prasyarat bagi keabsahan ibadah, ilmu juga menjadi media pencapaian derajat mulia dalam kehidupan dunia, sekaligus derajat tinggi di akhirat. Karenanya, ilmu musti dituntut sepanjang hayat tanpa pandang bulu dan guru, tanpa menghiraukan tempat dan waktu, baik ilmu-ilmu yang bersifat syar'i (ideal keagamaan) maupun ilmu-ilmu praktis di luar ilmu-ilmu keagamaan yang menunjang kehidupan manusia sebagai khalifatullāh fi al-arḍi yang diberitugas memakmurkan bumi.
Kelekatan Nawawi dengan isu ilmu pengetahuan dan kesadaran akan pentingnya ilmu pengetahuan juga mewarnai uraiannya dalam naskah ini. Dalam muqaddimah misalnya, Nawawi secara panjang lebar menjelaskan keutamaan ulama dan pentingnya ilmu secara umum dengan mengutip al-Qur'an, hadis, dan syair-syair motivatif sebelum menjelaskan pentingnya ilmu nahwu dalam dinamika keagamaan maupun keilmuan seorang muslim karena ia menjadi prasyarat wajib bagi penguasaan bahasa al-Qur'an yang merupakan pedoman pokok umat Islam.

Pendek kata, contoh-contohnya yang bernafaskan pendidikan dan faktual kehidupan merupakan usaha Nawawi dalam mengkampanyekan pentingnya pendidikan dan pemberantasan kebodohan demi kehidupan yang lebih baik.

\section{SIMPULAN DAN SARAN}

Contoh-contoh nahwu Nawawi sebagaimana paparan di atas menunjukkan satu keunikan tersendiri yang mencerminkan sosoknya yang multidimensional sebagai seorang 
pembelajar, ilmuwan, sufi, dan penulis yang nama dan karyanya tetap melekat di hati masyarakat Indonesia, terutama kalangan akademisi dan pesantren, sehingga ia pantas dianggap sebagai sosok yang perlu digali inspirasinya bagi pengembangan keilmuan dan keislaman di Indonesia saat ini. Semangat contohcontoh nahwu Nawawi yang menggelorakan kedinamisan juga bisa diterapkan dalam konteks kehidupan keislaman di Indonesia yang dalam banyak hal masih terpengaruh oleh budaya taklidisme dan klenik sebagaimana tercermin dalam tayangantayangan televisi dan maraknya korankoran kuning..

\section{DAFTAR PUSTAKA}

Asep Muhammad Iqbal, Yahudi dan Nasrani dalam al-Qur'an: Hubungan Antaragama menurut Syaikh Nawawi Banten, (Jakarta: Teraju, 2004)

Chaidar, Sejarah Pujangga Islam Syech Nawawi Albantani Indonesia, (Jakarta: CV. Sarana Utama, 1978),

Mamad S. Burhanuddin, Hermeneutika al-Qur'an ala Pesantren (Analisis terhadap Tafsir Marah Labid Karya KH. Nawawi Banten), (Yogyakarta: UII Press, 2006)
Nawawi al-Bantani, At-Tafsir al-Munir li Ma'ālim at-Tanzīl al-Musfir 'an Wujūh at-Ta'wīl -al-musammā tabaqan $l i$ ma'nahu- Marạ̄ Labīd li Kasyf Ma'na Qur'ān Majīd, (Cairo: Matba'ah al'Usmāniyyah, $1305 \mathrm{H}$ )

Nawawi, $A \dot{s}$-Simār al-Yāni 'ah Syarh arRiyāe al-Badi'ah (Cairo: Mustafa Babi al-Halabi, $1317 \mathrm{H})$, hlm. 1; Marāqi al'Ubūdiyyah, (Bandung: Al-Ma'arif, t.t.), hlm. 1; Salālim al-Fudalā', (Tasikmalaya: Toko Baru, t.t.)

Nawawi, Nur az-Zalām, (Surabaya: AlHidayah, t.t.),

Nawawi, Fath al-Majīd, (T.t.t.: Dar Ihya' al-Kutub al-'Arabiyyah, t.t.),

Nawawi, Qāmi' at-Tugyān, (T.t.t.: Dar Ihya' al-Kutub al-'Arabiyyah, t.t.),

Nawawi, Nașā'ih al-'Ibād, (Tasikmalaya: Toko Baru, t.t.)

Nawawi, Nihāyah az-Zain fi Irsyād alMubtadi'in, (Beirut: Dar al-Fikr, t.t.)

Nawawi, Kāsyifah as-Saja, (Cairo: AlMaṭba'ah al-Maimaniyyah, $1298 \mathrm{H}$ )

Rafi'uddin Ramli dan dan Muhammad Fakhri, Sejarah Hidup dan Silsilah Kyai Muhammad Nawawi Tanara, (CirumpakKeronjo, Tangerang: Yayasan Nawawi Tanara, 1399) 